\title{
South-South Collaboration for an Intellectual Property Rights Flexibilities Agenda
}

\author{
Henrique Zeferino de Menezes*
}

\begin{abstract}
This article analyses South-South initiatives for building an intellectual property (IP) flexibilities agenda, highlighting the particularities in this specific area of international relations as well as the difficulties encountered in building a common position. I start by outlining the changes and transformational dynamics in the international regime for the protection of IP, and examining how these changes, notably the proliferation of TRIPS-plus rules through preferential agreements, affect developing countries. Next, I examine the development of South-South collaboration as a strategic option for maintaining the policy space developing countries need to develop legal frameworks attuned to their specific needs and interests, and for building norms that strengthen IP flexibilities. I conclude that a strong and more purposeful response by countries like Brazil, India and China has been difficult to achieve for several reasons: i) the diversity of forms of protection included in the international negotiations; ii) the multiplicity of areas and public policies affected by IP regulations; and iii) domestic economic changes in developing countries.
\end{abstract}

Keywords: Intellectual Property Rights; Trade-Related Aspects of Intellectual Property Rights (TRIPS); South-South Collaboration; IP Flexibilities; IP Flexibilities Agenda.

\section{Introduction}

In October 2007, the United States Trade Representative (USTR), Susan Schwab, announced that the USA would open negotiations with certain countries over the adoption of a new international regulatory framework for the enforcement of intellectual property rights (IP), independent of any existing international institutions. The negotiations began in 2008 among representatives of the USA, the EU, Japan, Canada, Switzerland, Australia, South Korea, Mexico, Morocco, and New Zealand, resulting in the Anti-Counterfeiting Trade Agreement (ACTA), published in May 2011 (see ACTA 2011). One year later, the European Parliament rejected the agreement, but attempts to strengthen IP continued. In 2010, the USA joined the Trans-Pacific Partnership Agreement (TPP) negotiations with

\footnotetext{
* Federal University of Paraíba (UFPB), João Pessoa-PB, Brazil; hzmenezes@hotmail.com. ORCID iD 00000002-1385-7957.
} 
the aim of inserting specific IP rules similar to those contained in ACTA and other US trade agreements into the TPP. The TPP was finally signed early in $2016{ }^{1}$

The rapid negotiation of agreements as complex and controversial as the ACTA and TPP can be explained by the prior convergence of interests among the most important actors involved, especially the USA, Japan, and some EU countries. They had already expressed the need for these sorts of mechanisms, and had tested them on other occasions. ${ }^{2}$ Obviously, these 'prior understandings' did not prevent the emergence of some differences among those involved; however, the most relevant players, which had similar basic views about the spirit and general objectives of these agreements, agreed on the need to strengthen the IP rights of businesses globally, and cover unprotected new technologies. ${ }^{3}$ Moreover, the main demandeur of these kinds of agreements, the USA, had also focused its political efforts on strengthening the international IP regulations. Since the adoption of the Agreement on Trade-Related Aspects of Intellectual Property Rights (TRIPS) in 1995, the developed countries mentioned therein had been trying to strengthen international IP beyond its minimum standards. However, the difficulty of moving this maximalist agen$\mathrm{da}^{4}$ forward within the TRIPS Council forced them to adopt a forum-shifting strategy for advancing TRIPS-plus ${ }^{5}$ standards in other forums (Helfer 2004; Sell 2011).

The IP agreements negotiated after TRIPS reflect two interconnected dynamics that conform to the maximalist agenda. On the one hand, they form part of a broader strategy for negotiating TRIPS-plus agreements. On the other, they reflect a typical forum-shifting strategy. The negotiation of TRIPS-plus agreements in preferential or multilateral forums produces important regulatory impacts on IP, limiting the policy space countries need for developing appropriate developmental strategies and frameworks. Given this, the TRIPS flexibilities, which are important to ensure degree of balance between private protection and the public domain, have been jeopardised by the TRIPS-plus agreements (Gallagher 2005; Ruse-Khan 2005; Shadlen 2005; Correa 2010; Sell 2011). This strategy for improving protection through preferential negotiations also has an important international political effect: the fragmentation and emptying of multilateralism, reducing the capacity of developing countries to co-ordinate policy (Bannerman 2010; Geiger 2012).

The maximalist agenda pursued by the USA seeks to enhance the protection of IP, increase international harmonisation, and limit or eliminate the flexibilities in respect of private rights contained in TRIPS. It does so by negotiating agreements that increase the scope of what is considered the subject of protection and the duration of rights, and strengthening the enforcement mechanisms. This agenda has emanated from the biased perception of private organisations that IP violations have increased dramatically in recent years, damaging economies and the welfare of citizens, and that TRIPS was too flexible about the enforcement of rights and the protection of new and emerging technologies (Fink 2009).

In some ways, this forum-shifting strategy represents a response to the reluctance of some developing countries to accede to TRIPS-plus standards multilaterally, and to some important initiatives undertaken by them, as reflected in i) the 2001 Doha Declaration on TRIPS and Public Health; ii) the Development Agenda at the World Intellectual Property 
Organization (WIPO); iii) the demands for adapting IP rules to the Convention on Biological Diversity (CBD); and iv) national reforms aimed at making use of existing TRIPS flexibilities. Two weeks before Schwab's announcement, the WIPO General Assembly adopted the 45 recommendations of the Development Agenda, and created a permanent committee - the Committee on Development and Intellectual Property (CDIP) - to deal with this issue. The main principles and objectives of the Development Agenda are opposed to the strengthening of IP rights within and outside WIPO, focusing on preserving flexibilities, exceptions, and limitations to IP.

Therefore, these initiatives, which arose in response to the demands for strengthening IP regulations within and outside multilateralism, can be understood as part of a broad but fragmented and unco-ordinated agenda built by a group of non-developed countries for maintaining and deepening the remaining flexibilities in the multilateral IP regime. IP flexibilities allow countries to adapt their national IP systems to specific national demands, and to implement key public policies for social and economic development. Given this, the flexibilities agenda is directly related to the need of some developing countries to safeguard their freedom and capacity to make use of TRIPS flexibilities in order to adapt their national IP systems to their specific development needs. In recent years, China, India and South Africa have adopted or reformed their existing legislation in order to make proper use of the flexibilities contained in the agreement. In Brazil, some draft laws were presented and discussed, but reforms intended to align the national system with some important TRIPS flexibilities did not succeed.

Maintaining the policy space needed to adapt national IP laws to national interests requires a degree of autonomy, and the ability to use TRIPS flexibilities. Strengthening South-South collaboration is an important strategy for building a more responsive IP system which is more closely aligned to developmental needs and interests. Likewise, the creation of international standards compatible with the interests of developing countries requires a capacity for organisation and collaboration. As explained by Ahmed AbdelLatif (2005), co-ordination among developing countries refers to the pursuit of common positions with the objective of influencing international negotiations and rule-setting processes in a way that takes their interests into account. Agreeing with Narlikar's argument, Abdel-Latif explains that the limited bargaining power of individual developing countries makes coalitions an important instrument for achieving their objectives and increasing their bargaining power in international negotiations (Latif 2005: 29; see Narlikar 2013).

But what are the options and the real capacity of developing countries for aligning IP governance more closely with their own interests? Some prominent analysts have expressed optimism about the role of developing countries in adjusting IP rules, and the nature of these adjustments. Peter Drahos (2002), for instance, has advocated the creation of a counter-QUAD coalition by some large developing countries to 'counter-weight the agenda-setting powers of developed countries.6 Similarly, Jerome Reichman (2009) has suggested a 'counter-harmonization' alliance to take advantage of existing exemptions in international agreements in order to promote another kind of IP system. Rochelle Drey- 
fuss (2009), Peter Yu (2009) and Chidi Oguamanan (2011) have also pointed to the need for co-ordinated action by developing countries in reframing IP regulations in depth.

Historically, developing countries played a minor role in the framing of international IP regulations, and also struggled to co-ordinate their positions. IP rule-making was dominated by technologically advanced countries. Today, the increased power and capacity of some developing countries are clearly discernible, especially in their resistance to norms that do not reflect their interests. Large developing countries such as China, India and Brazil in particular have increased their ability and capacity to fight and limit the scope of TRIPS-plus rules, and even advance demands for flexibility that allow countries to choose the most appropriate public policies. However, the power of action cannot determine the capacity to maintain a co-ordinated flexibilities agenda.

This article discusses some South-South initiatives aimed at maintaining and strengthening IP flexibilities. To understand these initiatives, we have to look at the broader context and try to understand the risks posed by the US maximalist agenda and the need for the flexibilities agenda. To this end, the article consists of two main sections. In the first, I analyse the risks presented by the US maximalist agenda and its forum-shifting strategy to the multilateral IP regime. The multiplication of TRIPS-plus norms has raised concerns about imbalances in the rules that could further limit the existing TRIPS flexibilities. Some concerns are more broadly focused on the impairment or distortion of some agendas and demands that have made some progress in multilateral forums. Analysts fear that agreements negotiated outside the multilateral institutions may eventually undermine the discussions at the WTO, WIPO, and other relevant multilateral institutions.

In the second section, I deal specifically with South-South collaboration strategies in respect of IP. One important issue is to establish how these countries are dealing with the threat posed by the maximalist agenda, and advancing the flexibilities agenda instead. I first deal directly with the general resistance to the introduction of TRIPS-plus norms in multilateral institutions as well as preferential agreements that constrain the policy space of developing countries and detract from multilateralism. I also explore other forms of action and collaboration, including: i) the formation of permanent cross-issue alliances such as BRICS or IBSA in order to form coherent positions on certain themes; ii) coalitions for specific IP negotiations aimed at blocking other demands, or advancing the flexibilities agenda; and iii) technical co-operation and the diffusion of policies and mechanisms that promote the construction of national IP systems. In turn, collaboration among developing countries is beset with significant difficulties. In the specific case of IP negotiations, the situation is even more complex.

\section{The US maximalist agenda and the enforcement of IPR}

The current US maximalist agenda is the result of a process that began in the early 1980s. At that point, the USA began to campaign for the strengthening and harmonisation of international IP rules by exerting unilateral pressure on some trading partners, but especially by using a forum-shifting strategy that led to the insertion of a specific IP agreement 
into the multilateral trade regime during the GATT Uruguay Round (1986-1994). The adoption of TRIPS profoundly changed the IP regime, establishing a mandatory minimum standard for protecting all forms of knowledge; extending it to all WTO members; ${ }^{7}$ and establishing mandatory enforcement standards subject to oversight by the WTO Dispute Settlement Body. This resulted in the harmonisation of IP norms and its linkage to the logic of production and commerce, submitting a broad array of public policies to this trade-related dimension (Muzaka 2010; Musungu 2005). This severely constrained the policy space of developing countries to devise their own IP systems. However, TRIPS preserves certain flexibilities, allowing a minimum freedom for implementing its norms, and provides some leeway for adapting national IP protection systems to specific national demands. In sum, TRIPS has allowed some forms of limitation, exception, and rights exhaustion.

As noted previously, following TRIPS, the USA continued its attempts to strengthen and extend IP protection through TRIPS-plus agreements. Nonetheless, the period immediately after TRIPS was marked not only by attempts to strengthen standards of protection, but also by the emergence of greater assertiveness by some developing countries.

Different interpretations of the role of IP in development have given rise to new political disputes. These disputes and conflicts have fuelled the debates about inconsistencies in the IP rules, and the need for greater balance between private rights and access to knowledge. However, it has also led to the strengthening of the maximalist agenda adopted by the USA, prompting it to pursue an aggressive forum-shifting strategy, following emerging difficulties in the WTO TRIPS Council, to advance its IP agenda in various other forums.

It has done so in three ways. First, it has introduced demands in respect of IP in other multilateral institutions, including the WIPO (horizontal forum-shifting). Second, it has inserted chapters and clauses dealing with IP into preferential trade agreements and bilateral investment agreements (vertical forum-shifting) (Drahos 2003; Ruse-Khan 2010; Sell 2011). Third, it has attempted to reform national legislation to enforce IP nationally and globally. ${ }^{8}$

Multilaterally, two important agendas were negotiated at the WIPO which envisaged the conclusion of new treaties conforming to US legal standards: the Digital Agenda, and the Patent Agenda9 (Correa 2005; Musungu and Dutfield 2003). The USA also put pressure on the WIPO to strengthen the mandate of the Advisory Committee on Enforcement (ACE) to include 'soft law' norms and develop best practices and general enforcement orientations. Despite the existence of two international organisations with expertise to deal with IP that already have their own complex and controversial agendas, the USA further diversified international forums for building new TRIPS-plus provisions. In this way, two specific agendas gained prominence: the Standards Employed by Customs for Uniform Rights Enforcement (SECURE) at the World Customs Organisation (WCO), and the International Medical Products Anti-Counterfeiting Task Force programme (IMPACT) at the World Health Organisation (WHO). ${ }^{10}$ This process of horizontal forum-shifting has become so widespread that May (2007) has labelled it 'forum proliferation', and Munoz Telles (2009) as a policy of 'multiple forum capture'. 
More important is the US policy of negotiating TRIPS-plus agreements in non-multilateral instances. Since the adoption of TRIPS, the USA has entered into many new preferential trade agreements containing TRIPS-plus clauses. Despite their limited geographic impact, these agreements have undoubtedly been the most effective component of the maximalist agenda. More recently, the USA has paid greater attention to negotiating plurilateral agreements with like-minded partners.

ACTA and TPP are examples of this new face of the maximalist US strategy. ACTA was meant to encompass commitments in three areas: i) strengthening international cooperation; ii) improving enforcement practices; and iii) providing a strong legal framework for IP enforcement. It goes significantly further than the TRIPS minimum standards; strengthens the discretion of the authorities in civil enforcement, border measures, and criminal enforcement; and creates instruments for regulating IP rights in the digital environment (Bitton 2012; Michael 2010). As pointed out by Flynn, the TPP is also a plurilateral agreement that

[...] attempts to harmonize substantive patent and data protection law in the TPP membership to US standards on multiple controversial topics, including broadening scope of patentability, lengthening patent terms, imposing data exclusivity and patent/registration 'linkage' requirements, and restraining numerous flexibilities in the TRIPS Agreement (Flynn 2012: 153).

This strengthening of IP protection and enforcement procedures, and especially the way in which the agreement was negotiated, has worrisome implications, as Susan Sell (2011: 457) has noted:

[W] hile some of the substantive provisions are in fact TRIPS-plus and even US-plus, it is also TRIPS-minus insofar as it omits any TRIPS flexibilities, and U.S.-minus because it lacks provisions for fair use, limitations and exceptions to copyright, and due process provisions to protect the innocent. It sharply reduces policy space for developing countries to design appropriate policies for their public policy for innovation and economic development.

Flynn equally ponders the impact of exporting unbalanced standards that differ from those in the USA. Internal US legislation maintains a minimal balance between the interests of users and owners, maintaining important rights such as fair use. However, in international negotiations, the USA has emphasised the interests of rights holders only (Flynn 2012). ${ }^{11}$ In this context, bypassing multilateral institutions in order to advance a TRIPS-plus agenda is highly controversial, and has important consequences for developing countries.

In analysing international negotiations on IP, especially the US maximalist agenda and the role of South-South collaboration, it is important to take account of the broader international context for these negotiations, and to consider the structure of the interna- 
tional system and the configuration of forces among the main actors involved in its continuous adjustment. In this sense, we must observe how the proliferation of TRIPS-plus agreements could affect the system, how this may impact on the proposals and demands of some developing countries, and how TRIPS-plus norms affect their developing countries' policy space.

The US maximalist agenda has two main consequences: it reduces the policy space of countries signing treaties with the USA, and its preferential negotiations detract from multilateralism. Therefore, considering the impacts of TRIPS-plus norms and standards, especially those negotiated outside multilateralism helps to explain the reactions of developing countries within and outside multilateral institutions, and the importance of SouthSouth collaboration in strengthening their demands. Even more importantly, it is vital for developing countries to strengthen a flexibility agenda.

The main concerns about vertical forum-shifting is the fragmentation of international negotiations about IP and the weakening of multilateralism, caused by a proliferation of preferential agreements among like-minded countries. These kinds of negotiations avoid the contraposition of divergent positions, and a better balance of discussions and demands. Even more problematic is the fact that, in recent instances, these agreements have been negotiated in secret. Closed-door negotiations prevent relevant civil society organisations (CSOs) from participating. This distorts the broader negotiating process, and impairs the demands and agendas of developing countries.

Moreover, developing countries are concerned that preferentially negotiated systems and rules could become standards for future negotiations, as well as instruments for pressurising countries into adhering to certain TRIPS-plus standards. In this way, these kinds of agreements could become mandatory standards for future US trade partners. Without changing the overall structure of TRIPS, agreements like the ACTA and TPP are aimed at introducing higher standards that countries could adopt, while leaving significant room for the USA to exert pressure on its trading partners. As Schwab put it in 2007, the ACTA would be a new and broader enforcement reference that countries would adhere to voluntarily, but would also be a new standard for US trading partners (Office of the United States Trade Representative 2007). Even if it is never implemented, the ACTA was planned as the most advanced and most well-rounded part of a multifaceted strategy for strengthening specific TRIPS-plus rules by coercive or co-operative means. This is confirmed by the TPP, as well as other US demands.

These agreements could also serve as legal frameworks for later multilateral negotiations. This concern was not unrealistic. Ilias (2012) quotes Japanese trade officials as saying, 'We very much want to make ACTA a model for forming international rules within the WTO framework.' He also notes that several analysts have expressed concerns about the possibility of this type of agreement circumscribing multilateral processes. The option of escaping from multilateral institutions and consequently from the pressures and demands of transnational CSOs and the developing countries results in major imbalances in norms and standards. The difficulty in advancing the maximalist agenda in the WIPO and WTO has transformed the preferential negotiations into a viable solution for the USA, 
avoiding the resistance of countries such as Brazil, India, China, South Africa and the WIPO African Group in the process.

This approach to IP negotiations conflicts with the overwhelming trend in multilateral institutions towards protecting those TRIPS flexibilities that help developing countries to gain access to medicine, knowledge for educational purposes, and so on. ${ }^{12}$ The maximalist agenda and the fragmentation of the norm-setting process conflict with the flexibilities agenda, which has a much stronger focus on strengthening the limitations to flexibilities of IP rights. The US forum-shifting strategy works to limit the demands of developing countries, while undermining the credibility of multilateral institutions dealing with IP.

The maximalist agenda also poses risks for fragile South-South collaboration strategies and the coalition of developing countries supporting the demands for maintaining the flexibilities in the international IP regime. As noted previously, it works to empty the instances where these countries are advancing their demands, and pull them into the orbit of the developed economies. According to the European Commission Trade Office (2008): ' $\mathrm{t}$ ] he ultimate objective is that large emerging economies, where IP enforcement could be improved, such as China or Russia, will sign up to the global pact'. However, the absence of countries like China, India, and Brazil from the negotiations about an agreement on counterfeiting and piracy made this practically inefficient, and almost irrational. Inducing them into signing the agreement after the negotiations was unlikely (Yu 2013). ${ }^{13}$

Henceforth, the negotiation of preferential trade agreements and plurilateral agreements could lead to a fragmentation of the multilateral system - the most important forum for developing countries - and create new standards for other preferential and multilateral negotiations, leading to a further limitation of policy space. The conduct and strategies of some developing countries, especially those comprising the two most important international coalitions - the IBSA Dialogue Forum and BRICS - have made IP more prominent (Brazilian Ministry of Foreign Relations 2008). However, despite a range of efforts, it has proven difficult to formulate and adopt a coherent and active flexibilities agenda. In the next section, I will analyse some of these collaboration initiatives.

\section{Efforts to build a flexibilities agenda}

Collaboration among developing countries has been a fundamental strategy for limiting the maximalist agenda, and advancing the flexibilities agenda instead. This second agenda focuses on advancing a general understanding of and norms for exceptions and the limitations of rights, and increasing policy space for drafting national legislation. Some initiatives point in this direction. The most emblematic was the Doha Declaration on TRIPS and Public Health of 2001 which confirmed the use of compulsory license and parallel importation for countries without a capacity for pharmaceutical production. The amendments to TRIPS approved in December 2005 only entered into force in 2017 (Abbott and Reichman 2007). ${ }^{14}$ The WIPO Development Agenda of 2007 was inserted into these politics in order to sustain the flexibilities, exceptions and limitations in IP rules, and bar the IP harmonisation agenda. 
Other important unmet demands by developing countries point to the main features of their agenda, but also to important challenges. The relationship between TRIPS and the Convention on Biological Diversity (CBD) is a fundamental issue that is still unresolved (Vivas-Eugui 2010). Almost 20 years after the TRIPS Council started discussing this issue, developing countries still require a TRIPS amendment to incorporate prior informed consent, benefit sharing, and disclosure requirement. ${ }^{15}$ At the WIPO, more than a decade after the creation of the Intergovernmental Committee on Intellectual Property and Genetic Resources, Traditional Knowledge and Folklore (IGC), there is no sign of consensus on this issue.

International IP norms impact on national innovation and IP protection systems, and therefore on public policies vital to countries' interests. Given this, the political process of reconstructing the international IP regime is an important issue because it directly affects countries' development strategies (Maskus and Reichman 2005). Developing countries need a flexible system in order to align their national protection systems with specific public demands.

More recently, India, China, and South Africa have implemented or reformed their legislation to benefit from flexibilities in the multilateral rules. For a period after prematurely adopting some TRIPS-plus standards, Brazil sought to make intelligent use of TRIPS flexibilities, ${ }^{16}$ and reform its patent and copyright legislation in ways that would foster economic development. ${ }^{17}$

Current political dynamics and interpretations of the role of IP in development by some developing countries have created an environment in which this kind of response has become possible and prominent. In fact, given the shifts in geopolitical and economic power dynamics in the wake of the 2008 financial crisis, bottom-up innovation is beginning to have an impact on the system as a whole. In order to advance the flexibilities agenda, developing countries have been working outside and inside multilateralism to resist TRIPS-plus negotiations, reform or build new international rules and norms, ${ }^{18}$ and formulate national laws that observe the international rules while preserving the public interest and making effective use of existing flexibilities.

As noted earlier, international IP rules define, to some extent, national protection systems. Therefore, more flexible international rules provide more room for adapting national rules to countries' specific interests. Given this, it is clearly important for developing countries to co-ordinate their relevant strategies. While acknowledging that developing countries are interconnected, and cannot be understood in isolation, we will analyse South-South initiatives on three different levels:

i. Strengthening co-operation with key partners for building clear understandings of and political positions on international IP regulation;

ii. Building international coalitions for specific negotiations in international forums; and

iii. Formulating adequate national legislation for making use of flexibilities in international IP rules, and preserving the public interest through technical co-operation as well as mechanisms of policy diffusion. 
Policy diffusion and legal transplantation among countries are best understood as continuous processes emanating from previous contacts, existing co-operation, and coalitions. Organisations such as BRICS and IBSA are also built on previous initiatives and consultations. In the same sense, the building of international coalitions for specific negotiations emanates from shared economic interests, but also from the existence of political conditions for those involved.

However, over the past two decades, despite the growing power of developing countries, and the formation of coalitions among some of them, there have been no demands for a profound restructuring of the international IP regime. This emerges clearly from an analysis of their concrete strategies and actions. In general, developing countries have concentrated on consultations and collaboration about issues involving their specific interests, while trying to maintain policy space to adapt their national IP systems. The WIPO Development Agenda, as proposed but not as implemented, is an exception in the sense that it has been presented as an integrated proposal for reforming the international IP regime. The following analysis of the initiatives undertaken thus far points to the importance and potential of South-South Collaboration on IP, but also its difficulties.

BRICS is one of the most important coalitions of developing countries, especially because of its activism in respect of important economic issues, including IP and innovation. Prior to BRICS, India, Brazil and South Africa organised some of their positions within IBSA. Joint IBSA and BRICS declarations reveal their concerns about the proliferation of TRIPS-plus norms negotiated within and outside multilateral forums, and a belief that exceptions and limitations to international IP rules should be preserved and strengthened. Thus, IBSA and BRICS countries made important efforts to strengthen their co-operation on IP, and bolster their criticism of the maximalist agenda (Brazilian Ministry of Foreign Relations 2009).

At their 2011 summit, IBSA countries stated that they were opposed to attempts to develop new international standards for the enforcement of IP outside the WTO and WIPO, as these might give rise to abuses in the protection of rights, the construction of barriers to free trade, and the weakening of basic civil rights (IBSA 2011). Earlier, in 2009, they agreed to discuss a strategy for opposing the ACTA initiative. ${ }^{19}$ It is interesting to note that IP has been highlighted in all IBSA joint statements, related to the need to build a mechanism for protecting biodiversity, traditional knowledge and public health; strengthen 'the important role played by exceptions, exclusions, and limitations in bringing the necessary balance between Intellectual Property Rights and the public interest' (IBSA 2011); and effectively implement the WIPO Development Agenda.

At TRIPS Council meetings in 2010, China, India, South Africa, Brazil, and the African Group criticised the maximalist agenda and the forum-shifting strategy, arguing that some preferential agreements conflicted with TRIPS, threatened the balance provided by this agreement, and bypassed the existing multilateral processes in the WTO and WIPO (WTO 2010). As noted by Brazil, the ACTA contained elements that could lead to its conversion into a 'truly international organisation dealing with the enforcement of IP rights, a development whose impact on WIPO and the WTO, especially on capacity-building and 
technical assistance, are unpredictable at this stage' (Knowledge Ecology International 2010c).

The consequences, Brazil argued, would be the undermining of flexibilities and the policy space needed to allocate resources and work on specific public policies with the scale-up of TRIPS minimum standards. Instead, it said:

Brazil favours multilateralism and multilateral solutions: in IP matters, multilateral fora that have the legitimate credentials are the WTO and WIPO, whose deliberations are not only open to more than 140 member countries, but are also conducted in as transparent a way as possible, including representatives from civil society and NGO (Knowledge Ecology International 2010c).

The TRIPS Council was also an important forum for criticism by India, China, and Brazil:

As China and India noted at the June 2010 meeting of the WTO Council for Trade-Related Aspects of Intellectual Property Rights, ACTA has raised a wide variety of systemic problems within the international trading system. The agreement's heightened enforcement standards will upset the delicate balance struck in the TRIPS Agreement. It will also increase the incoherence and unpredictability of the international regulatory framework (Yu 2013: 3). ${ }^{20}$

Therefore, concerns about IP negotiations outside multilateral institutions recur in statements by BRICS and IBSA countries, as does the need to strengthen existing TRIPS flexibilities. Such statements also advocate the strengthening of co-ordinated action in multilateral institutions through important demands such as the WIPO Development Agenda:

The leaders agreed on the need for establishing trilateral cooperation in the field of IP with the aim of promoting a balanced international IP regime and to make a meaningful contribution to the economic and social progress of developing countries, ensuring access to knowledge, health care and culture (IBSA 2008) [...] The leaders noted with appreciation that IBSA countries were already co-coordinating their positions on a number of issues within the framework of the Development Agenda Group (IBSA 2011).

In the Goa Declaration following the $8^{\text {th }}$ BRICS Summit in 2016, member countries again emphasised the importance of economic multilateralism (BRICS 2016). This brings us to the second dimension of South-South collaboration in respect of IP: the building of coalitions for negotiating international norms and specific agendas. The implementation of WIPO Development Agenda is an example of this kind of collaboration among developing countries, but also of its limitations. This policy is connected to the strengthening 
of some joint perception among developing countries related to the need of more flexible international IP rules. The statement by the Brazilian delegation at the $40^{\text {th }}$ Series of Assemblies of WIPO member contains a clear description of its Brazil's proposed strategy for mainstreaming WIPO Development Agenda principles:

Our proposal is broad and horizontal, and approaches the WIPO work in all its dimensions. Its general relevance is, therefore, certainly not limited to any specific subsidiary organ inside WIPO. All of WIPO's organs and activities must clearly integrate the 'development' dimension of its work (World Intellectual Property Organisation 2004).

This strategy of mainstreaming the principles of the Development Agenda within WIPO would be based on instilling the principles of flexibility, exception, and limitations of IP rights in all WIPO institutions and fora. Immediately after the adoption of the agenda and its 45 recommendations, the Brazilian government formed a supporting coalition - the Development Agenda Group (DAG) - aimed at taking the spirit of the WIPO Development Agenda into other WIPO institutions. ${ }^{21}$ This group is dedicated to the defence of international rules that provide for greater flexibilities, exceptions, and limitations to patents and copyrights, but also for the enforcement of IP. Some important demands in this respect were presented to the WIPO Standing Committee of Patent (SCP), Standing Committee of Copyright (SCCR), and Advisory Committing of Enforcement (ACE). Since 2007, though, the WIPO Development Agenda's 45 recommendations have been poorly implemented. Despite the fact that the Agenda has not made much progress in recent years, DAG represents an important form of collaboration among developing countries in multilateral institutions.

IBSA and BRICS have also provided political spaces for transferring learning process about the laws and institutions that protect public interest and IP flexibilities. The establishment of permanent forums, resulting in meetings and summits, has facilitated socialisation processes, and stimulated the diffusion of ideas and policies. Morin and Gold (2014) have summarised studies that point to the important role of socialisation in policy diffusion.

In 2011, a BRICS Health Ministers meeting held in Beijing focused on the need to ensure that new international rules would not minimise TRIPS flexibilities, and that BRICS countries would remain resistant to TRIPS-plus rules. It resulted in the Beijing Declaration, which stated:

We are determined to ensure that bilateral and regional trade agreements do not undermine TRIPS flexibilities. We support the TRIPS safeguards and are committed to work together with other developing countries to preserve and promote, to the full, the provisions contained in the Doha Declaration on TRIPS and Public Health and of the Global Strategy and Plan of Action on Public Health, Inno- 
vation and Intellectual Property (BRICS Health Ministers' Meeting 2011).

According to the Brazilian representative at the meeting, the Indian health minister suggested that BRICS members should take co-ordinated action against coercive instruments relating to IP such as ACTA and other international agreements with TRIPS-plus characteristics (Brazilian Ministry of Foreign Relations 2011a).

More recently, in May 2014, an event entitled 'Access to medicines: challenges and opportunities for developing countries' was held in parallel with the opening of the World Health Assembly (Fraser 2014). It focused on two fundamental issues: (i) the need for BRICS countries to play a leading role in dealing with the poor access of reasonably priced medicines of peripheral countries; and (ii) the need for an international IP protection regime that allows countries to use instruments such as local production, compulsory licenses, parallel import, and other mechanisms to bring down medicine prices. The overall goal of the event was to discuss policies that would allow countries to ensure that their legislation made full use of current TRIPS flexibilities.

Similarly, at a Ministers of Commerce and Industry meeting during the Fifth BRICS summit in South Africa, some elements of the co-operation among those countries were also ranked. This included the need for continued collaboration in the multilateral arena, notably the WTO and WIPO, but also other relevant fora. The need to increase co-operation about IP was strongly emphasised in the document produced by the meeting. This included the need to i) enhance information exchange on IP legislation and enforcement via meetings and seminars; ii) jointly develop capacity-building programmes in respect of IP; and iii) promote co-operation among national IP offices (New 2013a).

In 2010, the governments of Brazil and China adopted a Joint Action Plan for 20102014 which established a Working Group on Intellectual Property, aimed at expanding co-operation in respect of IP, increasing understandings of the domestic legislation of each country, and strengthening co-operation in respect of IP enforcement and in relevant multilateral fora. During its third meeting, the Working Group made significant advances in harmonising the positions of these two governments on sensitive issues, including the enforcement of IP (Brazilian Ministry of Foreign Relations 2011b).

Some months later, Brazil, Russia, India, China, and South Africa entered into an agreement of co-operation in respect of IP. The agreement, called the BRICS Intellectual Property Offices Cooperation Roadmap, was approved in May 2013 at a conference in Magaliesburg, South Africa, and signed at an event parallel to the WIPO Annual General Assembly in September 2013. The agreement sets out seven lines of action, emphasising a commitment to increasing collaboration in international fora. ${ }^{22}$ Importantly, this document resulted from a broader process of collaboration among BRICS countries that, during the Durban Conference in 2012, had established the need for co-operation on innovation and other topics related to IP (New 2013b).

As noted previously, the main reason for developing countries to demand more flexible IP rules is to gain the policy space they need to build national systems that correspond with their national interests. TRIPS introduced far greater restrictions on countries in 
administering their IP systems, and the adoption of TRIPS-plus regulations would further decrease the already limited space for aligning IP laws with national demands As noted earlier, TRIPS left some room for manoeuvre, but the flexibilities agenda seeks to build new international standards which would provide space for recognising specific interests - especially soft laws in forums like the WIPO that would help to interpret the remaining flexibilities in TRIPS.

It is essential for developing countries in particular to adopt legislation that conforms with international rules but also with their national interests, making effective use of TRIPS flexibilities in the process. Learning from other country experiences plays an important role. Channels of socialisation and interaction among developing countries as well as past experiences are also important sources of learning and inspiration for the building and reforming domestic legislation.

As noted previously, TRIPS left some room for adapting IP rules to national contexts, and limiting private protection of knowledge. More recently, developing countries have been working on political processes and national reforms to adjust their legislation to the TRIPS minimum standards, while making full use of the available flexibilities.

Despite having adopted stricter rules than the TRIPS minimum standards, Brazil has introduced some important innovations. 'Prior consent' for granting pharmaceutical patents and the use of compulsory licensing in case of insufficient exploitation are the most important examples. India and China reformed their patent laws in 2005 and 2008, making use of TRIPS flexibilities to adapt their legislation to specific national demands and development strategies. One of the most important changes was related to the construction of higher patentability requirements, especially the inventive step of requirement and novelty, in order to encourage sequential innovation by local entrepreneurs, and sustain a strategy for economic and technological development. India has introduced important limits on patentable subject matter in its new Patent Law. ${ }^{23}$ China reformed its patent law in 2008 and, like India, implemented a stricter application of novelty. An invention must possess prominent and substantive differentiating characteristics, as well as represent a significant improvement, when compared to the prior art (Zhang 2014).

Different forms of use of protected knowledge are another important flexibility in TRIPS. In India, the government or any person authorised by it may use a patented invention for governmental use, with financial compensation. Compulsory licenses are the most important way of authorising third parties to use protected knowledge. The Doha Declaration broadened the understanding of the use of knowledge for public health; however, it is not only used to protect health. In 2008, China reformed its patent law to implement a measure similar to Brazil. If the patent holder in that country, after three years from the date of the grant, and four years from the date of filing, has not exploited or sufficiently exploited the subject matter of the patent, without any justifiable reason, a compulsory license may be granted. This demonstrates that experiences of the use of TRIPS flexibilities can be shared among countries.

Developing countries encounter great difficulties in building strong alliances and deeper reformist agendas, largely due to the typical dilemmas in respect of trade issues 
and other economic areas, but also due to the specific applications of IP regulations. In general, the difficulties or lack of interest in building a deeper IP reform agenda among developing countries can be attributed to the obstacles of defining a clear common denominator for their positions. This results from the complexity of the international IP regime. Firstly, the IP regime encompasses a vast range of types of protection that affects important areas of international political economy, and overlaps with other international regimes (trade and investment regulations; access to knowledge, innovation and industrial policies, public health, food security and agriculture; biodiversity, traditional knowledge; copyright and internet regulations, and so on).

Co-ordination is also complicated by growing divergences among developing countries on some specific issues. The economic and productive transition beyond the 'frontier of innovation' tends to lead to more fragmented positions on patents and copyright, but also on the use of biodiversity and other IP regulations. The development of more technology-intensive production tends to demand a pro-IP agenda within these countries, creating contradictory positions among them. Therefore, the growing complexity of developing countries' economies, the multiplication of instances in which IP themes are negotiated, and the multiplication of IP-related themes tends to create obstacles to deeper South-South collaboration. The multiplication of demands for preferential negotiation may increase the costs for some of these countries if they do not adhere to international agreements with TRIPS-plus clauses. All of this creates even greater obstacles to building a joint agenda for the deeper reform of international IP norms.

\section{Final remarks}

Historically, developing countries have played a minor role in building international IP norms. Technologically developed countries and their companies have predominated. In recent years, especially following the 2008 financial crisis, developing countries have begun to play a more active role, especially in resisting norms that do not reflect their interests. Given this, some of the actions and reactions recorded in this article are indeed no surprise. Today, the increasingly powerful developing countries are unlikely to buy into systems they have not helped to shape. Accordingly, large developing countries have increased their ability to limit the scope of TRIPS-plus rules, and advance demands for flexibility that would allow them to develop public policies most appropriate to their specific interests. BRICS countries are working to collectively advance their demands, and limit the efforts of developed countries to build TRIPS-plus rules multilaterally. However, their capacity of action alone does not fully explain their efforts to maintain a joint agenda for exploiting IP flexibilities.

South-South collaboration can help build some instruments for shaping the IP system in a way that better meets the interests of developing countries. As noted earlier, developing countries need the capacity and space to make use of TRIPS flexibilities without submitting to the pressures from developed countries to accede to TRIPS-plus commitments. Likewise, the creation of international standards that bolster the interests of developing 
countries demand a capacity for organisation and collaboration. The adequacy of TRIPS for existing CBD provisions is an important example of a demand from developing countries (especially megadiverse ones like Brazil, China and India) that will not be achieved without strong policy co-ordination.

On the other hand, the BRICS countries seem reluctant to formulate joint demands for deep reforms to the international IP protection system. Over the past two decades, there have been no demands for a profound restructuring of the IP regime beyond the WIPO Development Agenda.

One important conclusion is that developing countries face significant difficulties in building an agenda for thoroughly reforming the IP regime. Their main problem is that they find it difficult to define a clear common denominator for their positions. However, some factors suggest that a deeper and more lasting collaboration is possible, and that these countries share some important characteristics that could enable them to find a minimal common denominator. For instance, they are all marked by huge internal economic and social inequalities: therefore, access to knowledge, essential medicines, and human rights remains an economic and political imperative. They also have large indigenous communities, and have landscapes rich in biodiversity. In turn, it has become clear that attempts to harmonise and strengthen international IP protection have adversely affected developing countries, especially those pursuing a 'catch-up' strategy. Most importantly, the private protection of knowledge affects large segments of public policies that are essential to developing countries. Opening and defending the policy space they need to devise national protection systems suited to their developmental needs would constitute an effective South-South policy co-ordination agenda.

\section{Notes}

1. It was signed by the USA, Japan, Australia, Brunei, Canada, Chile, Peru, Malaysia, México, New Zealand, Singapore and Vietnam. However, on 23 January 2017, US President Donald Trump signed a decree withdrawing the USA from TPP. The implications of this decision for US strategy and regional economic integration are still open to interpretation.

2. This emerges from the statements and initiatives of the G8, with the establishment of the IP Task Force on Anti-counterfeiting and Piracy and the Heiligendamm Dialogue as two important examples.

3. The allegations are that new technologies resulting from recent technological transformations, especially Internet 'products' and new discoveries in biotechnology, are not covered by TRIPS.

4. The concept of a 'maximalist agenda' is discussed by Debora Halbert (2011).

5. TRIPS-plus agreements are those containing broader and deeper provisions on IP than TRIPS.

6. For international trade negotiations, the United States, the European Community countries, Japan and Canada are known as the 'Quad States'. So, Peter Drahos (2002) suggests the creation of a developing country group to counterweight to the Quad States in the negotiations of IP rules.

7. Least developed countries were given a transition period for fully implementing TRIPS that was recently extended until 1 July 2021.

8. Over the past three decades, the USA has changed its national legislation numerous times, but always toward the strengthening of IP rules and punishment for infractions. Recently, the Prioritizing Resources and Organization of Intellectual Property (PRO-IP) Act created the Office of US Intellectual Property Rights Enforcement Coordinator (IPEC) to support and co-ordinate all US initiatives on IP enforcement 
nationally and abroad.

9. The Digital Agenda encompasses two important treaties: the WIPO Copyright Treaty, and the WIPO Performances and Phonograms Treaty. The Patent Agenda covers important initiatives such as the adoption of the Patent Law Treaty (PLT), the reform of the Patent Cooperation Treaty (PCT), and the negotiation of the Substantive Patent Law Treaty (SPLT).

10. SECURE seeks the establishment of a relationship between the counterfeit of medicines and public health risks to enlarge the scope of practices regarded as illegal, and provide new coercive mechanisms for governments. It has also suggested that the WHO should develop a 'model law' for IP to shape national and international systems and practices in a broader way than TRIPS. The proposal submitted to the WHO has some similarities with SECURE. It also focuses on customs and enforcement measures.

11. Band (2012) concurs as follows: 'The US IP system is based on a careful balance between creators' interests in the control of their work, and societies' interest in the access to those works. SOPA, PIPA, and TPP lack this historic balance. [...] The US proposal for the TPP IP chapter lacks the balance found in US IP law.'

12. Several international organisations and international NGOs have recognised the importance of IP flexibilities to ensure social and human rights. PNUD, UNCTAD, and UNAIDS have all recently published documents and reports in support of TRIPS flexibilities.

13. The proposal for the establishment of the ACTA Committee - tasked with examining 'matters concerning the development of the Agreement', deciding upon 'the terms of accession of any member of the WTO', and inviting 'those signatories not parties to this Agreement to participate in the Committee's deliberations on those rules and procedures' - likewise reinforces the view that the prime addressees are other countries, especially developing countries.

14. In May 2007, the World Health Assembly (WHA) adopted a resolution mandating the provision of technical assistance for the use of TRIPS flexibilities and other relevant decisions to promote access to pharmaceutical products. The USA disassociated itself from the decision, and in 2008, the WHO adopted the Global Strategy and Plan of Action on Public Health, Innovation and Intellectual Property (GSPOA).

15. The last proposal - the 'Draft Decision to Enhance the Mutual Supportiveness between the TRIPS Agreements and the CBD' - was sent to the TRIPS Council in April 2011.

16. The 'prior consent' of the National Health Surveillance Agency (ANVISA) is one of the most important uses of TRIPS flexibilities in Brazil.

17. Project of Revision of the Patent Law (Revisão da Lei de Patentes: inovação em prol da competitivdade).

18. The main objective is to reform TRIPS itself, because it lays down binding rules. It is also important to negotiate and build rules in other international organisations, such as the WIPO, the WHO and the CBD, for the establishment of soft law. Norm-setting in these institutions can build understandings for interpreting TRIPS, and strengthen pro-flexibility positions to reform national laws. This also includes the use of the WTO Dispute Settlement Body to consolidate interpretations of the importance of flexibilities, and clarify dubious points in TRIPS.

19. This IBSA meeting to discuss strategies for the construction of a common strategy to oppose ACTA preceded a meeting with representatives and think-tanks in Geneva on the sidelines of the $5^{\text {th }}$ session of $\mathrm{ACE} / \mathrm{WIPO}$.

20. Also see New 2010; Knowledge Ecology International 2010a, 2010b.

21. This group, formally established in 2010, comprised 18 countries, including Brazil, India and South Africa.

22. The seven lines of action were: i) training of IP Office Staff; ii) promotion of public awareness on IP in BRICS countries; iii) examiner exchange programme; iv) information services on IP, e.g. exchange of patent documentation, taking account of local legislation; v) IP/Patent processes and procedures including search, classification and translation; vi) National IP Strategy and IP Strategy for enterprises; and vii) collaboration in International Forums as required and subject to consensus.

23. In India's new patent law, inventive activity means an invention that a) involves a technical advance compared to existing knowledge, b) has economic relevance, or c) both, and is not obvious to a Technical in the subject. 


\section{References}

Abdel-Latif, Ahmed. 2005. 'Developing Country Coordination in International Intellectual Property Standard-Setting. South Centre TRADE Working Papers No. 24.

. 2011. 'Change and Continuity in the International Intellectual Property System'. The WIPO Journal 3 (1): 36-55.

Abbott, Frederick and Jerome Reichman. 2007. 'The Doha Round's Public Health Legacy: Strategies for the Production and Diffusion of Patented Medicines under the Amended TRIPS Provisions'. Journal of International Economic Law 10 (4): 921-987.

Anti-Counterfeiting Trade Agreement (ACTA). 2011. At http://www.mofa.go.jp/policy/economy/i_ property/pdfs/acta1105_en.pdf [Accessed on 25 July 2014].

Band, Jonathan. 2012. 'The SOPA-TPP Nexus'. PIJIP Research Paper No. 6. Washington, DC: American University College of Law.

Bannerman, Sara. 2010. 'WIPO and the ACTA Threat'. PIJIP Research Paper No. 4. Washington, DC: American University College of Law.

Biadgleng, Ermias. 2007. 'Analysis of the Role of South-South Cooperation to Promote Governance on Intellectual Property Rights and Development'. South Centre Research Papers No. 14.

Bitton, Miriam. 2012. 'Rethinking the Anti-counterfeiting Trade Agreement Criminal Copyright Enforcement Measures'. The Journal of Criminal Law \& Criminology 102 (1): 67-118.

Brazilian Ministry of Foreign Relations. 2008. 'Document Da SERE para Brasemb Pequim. Diplomatic Communication. Brasília.

2009. 'Document Da DELBRASOMC para Exteriores em 27/11/2009 (MVA) Propriedade Intelectual. Sistema Internacional de 'Enforcement”. Diplomatic Communication. Brasília.

2011a. 'Document De Brasemb Pequim para Exteriores em 18/07/2011 (AFF)'. Diplomatic Communication. Brasília.

2011b. 'Document 'Da SERE para Brasemb Pequim Em 06/06/2011'. Diplomatic Communication. Brasília.

BRICS Health Ministers' Meeting. 2011. BRICS Health Ministers' Meeting: Beijing Declaration. 11 July.

BRICS. 2016. VIII BRICS Joint Summit: Goa Declaration.

Correa, Carlos. 2005. 'An Agenda for Patent Reform and Harmonization for Developing Countries'. In Bellagio Dialogue on "Intellectual Property and Sustainable Development: Revising the agenda in a new context". Bellagio, Italy, 24-28 September 2005. Geneva: International Center for Trade and Sustainable Development (ICTSD).

2010. 'TRIPS and TRIPS-plus Protection and Impacts in Latin America'. In Daniel Gervais (ed). Intellectual Property, Trade and Development: strategies to optimize economic development in a TRUPS-plus Era. Oxford: Oxford University Press.

Drahos, Peter. 2002. 'Developing Countries and International Intellectual Property Standard-setting. The Journal of World Intellectual Property 5 (5): 765-789.

. 2003. 'Expanding Intellectual Property's Empire: the Role of FTAs', Grain. At http://www. grain.org/rights/tripsplus.cfm?id=28 [Accessed on 01 September 2008]. 
Dreyfuss, Rochelle. 2009. 'The Role of India, China, Brazil and Other Emerging Economies in Establishing Access Norms for Intellectual Property and Intellectual Property Lawmaking. Institute for International Law and Justice Working Paper 05.

Duffy, John F. 2002. 'Harmony and Diversity in Global Patent Law'. Berkeley Technology Law Journal 17: 685-726.

European Commission Trade Office. 2008. The Anti-Counterfeiting Trade Agreement (ACTA) Fact Sheet. At http://trade.ec.europa.eu/doclib/docs/2008/october/tradoc140836.11.08.pdf [Accessed on 25 July 2014].

Fink, Carsten. 2009. 'Enforcing Intellectual Property Rights: An Economic Perspective'. Geneva: International Centre for Trade and Sustainable Development (ICTSD).

Flynn, Sean. 2011. 'ACTA's Constitutional Problem: The Treaty Is Not a Treaty'. American University International Law Review 26 (3): 903-926.

Flynn, Sean, Brook Baker, Margot Kaminski and Jimmy Koo. 2012. 'The U.S. Proposal for an Intellectual Property Chapter in the Trans-pacific Partnership Agreement'. American University International Law Review 28 (1): 105-205.

Fraser, Julia. 2014. 'BRICS Ministers Join Forces for Access To Medicines'. Intellectual Property Watch [online]. 20 May. At https://www.ip-watch.org/2014/05/20/brics-ministers-join-forces-foraccess-to-medicines/ [Accessed on 20 September 2015].

Gallagher, Kevin P (ed). 2005. Putting Development First: The Importance of Policy Space in the WTO and International Financial Institutions. New York: Zed Books.

Geiger, Christophe. 2012. 'Weakening Multilateralism in Intellectual Property Lawmaking: A European Perspective on ACTA'. The WIPO Journal 3 (2): 166-178.

Halbert, Debora. 2011. 'The Politics of IP Maximalism'. The WIPO Journal 3 (1): 81-93.

Homere, Jean R. 2010. 'Intellectual Property, Trade and Development: A View from the United States'. In Daniel Gervais (ed), Intellectual Property, Trade and Development: Strategies to Optimize Economic Development in a TRIPS-plus Era. Oxford: Oxford University Press.

IBSA. 2008. III IBSA Joint Summit: New Delhi Declaration.

2011. V IBSA Joint Summit: Tshwane Declaration.

Ilias, Shayerah. 2012. 'The Proposed Anti-Counterfeiting Trade Agreement: Background and Key Issues.' Congressional Research Service. Washington, DC.

Khor, Martin and Sangeeta Shashikant (eds). 2009. Negotiating a 'Development Agenda' for the World Intellectual Property Organization (WIPO). Penang: Third World Network.

Knowledge Ecology International [online]. 2010a. 'India’s intervention on 'TRIPS plus IPR Enforcement' as delivered at the WTO TRIPS Council on 9 June 2010'. 10 June. At http://keionline.org/ node/864 [Accessed on 18 September 2015].

2010b. 'China describes TRIPS Council proposal on ACTA and other plurilateral enforcement agreements. 7 July. At http://keionline.org/node/883 [Accessed on 18 September 2015].

2010c. 'Brazil intervention at TRIPS: ACTA'. 29 October. At https://www.keionline.org/21412/ [Accessed on 18 September 2015].

Maskus, Keith and Jerome Reichman (eds). 2005. International Public Goods and Transfer of Technology under a Globalized Intellectual Property Rights Regime. Cambridge: Cambridge University Press. 
May, Christopher. 2007. The World Intellectual Property Organization: Resurgence and the Development Agenda. New York: Routledge.

Michael, Gabriel. 2010. 'ACTA, Fool: Explaining the Irrational Support for a New Institution'. PIJIP Research Paper No. 7. Washington, DC: American University College of Law.

Morin, Jean-Frederic and Edward Gold. 2014. 'An Integrated Model of Legal Transplantation: The Diffusion of Intellectual Property Law in Developing Countries'. International Studies Quarterly 58 (4): 781-792.

Munoz Telles, Viviana. 2009. 'The Changing Global Governance of Intellectual Property Enforcement: A New Challenge for Developing Countries'. In Xuan Li and Carlos Correa (eds), Intellectual Property Enforcement: International Perspectives. Cheltenham: Edward Elgar.

Musungu, Sisule. 2005. 'Rethinking innovation, development and intellectual property in the UN: WIPO and beyond', TRIPS Issues Papers 05. Ottawa: Quaker International Affairs Programme (QIAP).

Musungu, Sisule and Graham Dutfield. 2003. 'Multilateral Agreements and a TRIPS-plus World: the World Intellectual Property Organization (WIPO)', TRIPS-plus Issues Papers 03. Geneva/Ottawa: Quaker United Nations Office (QUNO) and Quaker International Affairs Programme (QIAP).

Muzaka, Valbona. 2010. 'Linkages, Contests and Overlaps in the Global Intellectual Property Rights Regime. European Journal of International Relations 17 (4): 755-776.

.2012. 'Contradictions, Frames and Reproductions: The Emergence of the WIPO Development Agenda'. Review of International Political Economy 20 (1): 215-239.

Narlikar, Amrita. 2013. International Trade and Developing Countries: Bargaining Coalitions in the GATT and WTO. London: Routledge.

New, William. 2010. 'China, India to Raise Concerns at WTO About TRIPS-Plus Measures, Intellectual Property Watch [online]. 03 June. At https://www.ip-watch.org/2010/06/03/china-india-toraise-concerns-at-wto-about-"trips-plus"-measures-acta/ [Accessed on 20 September 2015].

. 2013a. 'Innovation, IPR Cooperation Among Top Priorities For BRICS'. Intellectual Property Watch [online]. 26 March. At https://www.ip-watch.org/2013/03/26/innovation-ipr-cooperation-among-top-priorities-for-brics/[Accessed on 20 September 2015].

. 2013b. 'BRICS Launch Their Own Plan For IP Cooperation; India Defends Itself'. Intellectual Property Watch [online]. 27 November. At https://www.ip-watch.org/2013/11/27/brics-launchtheir-own-plan-for-ip-cooperation-india-defends-itself/ [Accessed on 20 September 2015].

Office of the United States Trade Representative. 2007. 'Ambassador Schwab Announces U.S. Will Seek New Trade Agreement to Fight Fakes'. Eashington, DC At https://ustr.gov/ambassador-schwabannounces-us-will-seek-new-trade-agreement-fight-fakes [Accessed on 25 July 2014].

Oguamanan, Chidi. 2011. 'IP in a Global Governance: A Venture in Critical Reflection'. WIPO Journal 2 (2): 196-216.

Reichman, Jerome. 2009. 'Intellectual Property in the Twenty-First Century: Will the Developing Countries Lead or Follow?' Houst Law Review 46 (4): 1115-1185.

Ruse-Khan, Henning Grosse. 2009. 'Policy Space for Domestic Public Interest Measures Under Trips'. South Center Research Paper No. 22. 
2010. 'Protecting Intellectual Property Rights under BITs, FTAs, and TRIPS: conflicting re-

gimes or mutual coherence?.' Max Planck Institute for Intellectual Property and Competition Law Research Paper No. 11-02.

Shadlen, Ken. 2005. 'Policy Space for Development in the WTO and Beyond: The Case of Intellectual Property Rights', Global Development and Environment Institute Working Paper No. 05-06. Medford: Tufts University.

Sell, Susan K. 1995. 'The Origins of Trade-Based Approach to Intellectual Property Protection: the role of industry associations.' Science Communication 17 (2): 163-185.

. 2010. 'The Global IP Upward Ratchet, Anti-Counterfeiting and Piracy Enforcement Efforts: the State Of Play', PIJIP Research Paper No. 15. Washington, DC: American University Washington College of Law.

2011. 'TRIPS Was Never Enough: Vertical Forum Shifting, FTAs, ACTA, and TPP'. Journal of Intellectual Property Law 18 (2): 447-478.

Slade, Alison. 2011. 'Articles 7 and 8 of the TRIPS Agreement: a Force for Convergence within the International IP System. The Journal of World Intellectual Property 4 (6): 413-440.

Vivas-Eugui, David and María Julia Oliva. 2010. 'Biodiversity Related Intellectual Property Provisions in Free Trade Agreements', ICTSD Issue Paper No. 4. Geneva: International Centre for Trade and Sustainable Development.

World Intellectual Property Organization. 2004. 'Proposal for the establishment of a Development Agenda for WIPO'. Geneva.

World Trade Organization. 2010. 'Council debates anti-counterfeiting talks, patents on life'. At http://www.wto.org/english/news_e/news10_e/trip_08jun10_e.htm [Accessed on 25 July 2014].

Yu, Peter. 2009. 'Building Intellectual Property Coalitions for Development'. In Jeremy de Beer (ed), Implementing WIPO’s Development Agenda. Ottawa: Wilfrid Laurier University Press, pp. 79-99.

. 2013. 'The ACTA/TPP Country Clubs'. At http://www.peteryu.com/beldiman.pdf [Accessed on 02 May 2015].

Zhang, Haiyang. 2014. 'Patent Institution, Innovation and Economic Growth in China'. In Ross Garnaut, Cai Fang and Ligang Song (eds), Deepening Reform for China's Long-term Growth and Development. Canberra: ANU Press, pp. 507-530.

\section{Acknowledgments}

I would like to thank the National Council for Scientific and Technological Development (CNPq) and the National Institute of Science and Technology for Studies on the United States (INCT-INEU) for funding the project 'Implementing the WIPO Development Agenda: mainstreaming the principles of the Agenda and the US resistance'; and Professors Leonardo Ramos (PUC-MG) and Marcos Costa Lima (UFPE) for commenting on earlier drafts of this article.

\section{About the author}

Henrique Zeferino de Menezes is Professor in the Department of International Relations and the Graduate Programme in Political Science and International Relations of the Federal University of Paraíba (UFPB). He is also a researcher at the National Institute of 
Science and Technology for Studies on the United States (INCT-INEU). He has recently conducted research on intellectual property rights, the Sustainable Development Goals, and global health. Papers published in recent years include 'Pesquisa e extensão como contribuição da universidade na implementação dos ODS no Brasil', and 'A Estratégia Norte-Americana de Forum Shifting para Negociação de Acordos TRIPS-Plus com Países da América Latina. In 2017, he organised the books Propriedade Intelectual, Inovação Tecnológica e Saúde and A Economia Política do Governo Obama.

\title{
Colaboração Sul-Sul para uma Agenda de Flexibilidades de Direitos de Propriedade Intelectual
}

\begin{abstract}
Resumo: $\mathrm{O}$ artigo analisa as iniciativas de colaboração Sul-Sul no processo de construção de uma agenda de flexibilidades em propriedade intelectual, apontando para as particularidades da colaboração nessa área específica das relações internacionais, assim como as dificuldades de construção de uma posição comum e uma agenda de demandas mais incisiva por parte desses países. Inicialmente, são apresentadas as mudanças e dinâmicas de transformação no regime internacional de proteção a propriedade intelectual e como essas mudanças, que caminham no sentido da proliferação de regras TRIPS-plus em instâncias preferenciais, podem afetar os países em desenvolvimento e suas estratégias de desenvolvimento e inserção internacional. Por sua vez, é discutido como a colaboração Sul-Sul aparece como uma opção estratégica para a manutenção do policy space desses países, assim como para a construção de normativas que fortaleçam as flexibilidades de direitos de propriedade intelectual. Entretanto, o que se percebe é que uma resposta mais propositiva por parte de países como Brasil, Índia e China é de difícil concretização por diversas razões. Dentre os principais fatores estariam: i) a ampla diversidade de formas de proteção incluídas nas negociações internacionais; ii) a multiplicidade de áreas e políticas públicas afetadas pelas regulamentações em propriedade intelectual; iii) mudanças econômicas domésticas nos países em desenvolvimento.
\end{abstract}

Palavras-Chave: Propriedade Intelectual; Acordo sobre Aspectos dos Direitos de Propriedade Intelectual Relacionados ao Comércio - TRIPS; Colaboração Sul-Sul; Flexibilidades; Agenda de Flexibilidades.

Received on 6 February 2017, and approved for publication 21 November 2017.

\section{(cc) BY-NC} https://creativecommons.org/licenses/by-nc/4.0/ 